\title{
Risk of hepatitis A infection in sewage workers
}

\author{
Ruairí Brugha, Julia Heptonstall, Paddy Farrington, Sheila Andren, Keith Perry, \\ John Parry
}

\begin{abstract}
Objective-To evaluate the risk of hepatitis A virus (HAV) infection among sewage workers from occupational exposure to raw sewage.

Methods-An analytical cross sectional study of 241 company employees with possible occupational exposure to sewage in a large water and sewerage company was carried out. Previous exposure to hepatitis $A$ virus infection was assessed, as were its associations with possible risk factors. Results-Frequent occupational exposure to raw sewage was a significant risk factor for HAV infection, independently of other known risk factors (odds ratio 3.73, 95\% confidence interval 1.48 to 9.37 ). Of 50 employees who reported occupational exposure to raw sewage most of the time, $\mathbf{3 0}$ $(60 \%)$ had had HAV infection.

Conclusion-Employees who are likely to be at risk of frequent exposure should have their immunity ensured. The salivary assay for IgG anti-HAV used in the study was highly specific and would be suitable for prevaccination testing of older employees, who are more likely to be immune. (Occup Environ Med 1998;55:567-569)
\end{abstract}

Immunisation Division, Public Health Laboratory

Service,

Communicable

Disease Surveillance

Centre, London, UK

R Brugha

J Heptonstall

P Farrington

Health and Safety, Thames Water Utilities, Mogden STW, Mogden Lane, Mogden, Isleworth, Middlesex, UK

S Andren

Hepatitis and

Retrovirus Laboratory

Virus Reference

Division, Central

Public Health

Laboratory, London,

UK

K Perry

J Parry

Correspondence to: Dr Ruairí Brugha, Department of Public Health, Health Policy Unit, London School of Hygiene and Tropical Medicine, Keppel St, London WC1E 7HT, UK

Accepted 24 February 1998 to raw sewage. Thames Water Utilities provided the largest sampling frame of potentially at risk employees in any single such company in the United Kingdom; and the company wished to develop a hepatitis A vaccination policy, as part of its statutory duty to base company practice on risk assessments. ${ }^{8}$

\section{Subjects and methods}

The three main drainage depots and three large sewage treatment works serving the London area, where employees at highest risk of exposure to raw sewage were based, were selected for the study. All employees who were judged by their managers to be at risk of exposure to raw sewage were included in the sample, as was an additional group of manual employees working at adjacent Thames Water sites who had no known exposure to sewage. Types of workers that managers considered likely to be at risk of occupational exposure, in order of importance, were: sewerage workers, who enter sewers to unblock pipes and carry out maintenance work; flushers and fitters, who clean inlet screens and sewage pumps; and electricians, supervisors, and engineers whose work involves infrequent contact with raw sewage. Untreated sewage is found in the sewerage system (pipes) and at the inlet to the sewage works where it is rendered safe for disposal.

An information sheet was sent to each potential study participant, explaining the nature and purpose of the study. Two company occupational health nurses visited work sites each morning, discussed the study with the employees in groups and one to one meetings, and obtained signed informed consent from individual workers. Repeated visits to each site were made over a period of months to make contact with employees who had been working on other shifts, or on leave, at earlier visits. Despite repeated visits to each site, it was not possible to contact every member of the sample.

A structured questionnaire was adminstered to each participant by a health worker. Indicators of occupational exposure were: number of years in any employment (current and previous) which could have involved contact with sewage; respondents' estimates of the proportion of their time spent working in the sewers, working with raw sewage and with treated sewage-each categorised as most, some, or none of the time; and number of times ever splashed with raw sewage, with a closed response set of answers in five categories ranked from never to $\geqslant 20$ times. Questions were included to elicit information on nonoccupational risks: age, educational level (used as a proxy for socioeconomic status), ethnicity (subsequently coded as white or non-white), country of birth (subsequently coded as United Kingdom or not United Kingdom), regions of the world visited (subsequently ranked in five 
Table 1 Cumulative prevalences of anti-HAV positivity

\begin{tabular}{lllllr}
\hline $\begin{array}{l}\text { Cumulative age } \\
(y)\end{array}$ & $\begin{array}{l}\text { Proportion } \\
\text { anti-HAV } \\
\text { positive }\end{array}$ & $(\%)$ & $\begin{array}{l}\text { Cumulative age } \\
(y)\end{array}$ & $\begin{array}{l}\text { Proportion } \\
\text { anti-HAV } \\
\text { positive }\end{array}$ & $(\%)$ \\
\hline$\geqslant 20$ & $79 / 224$ & $(35)$ & $<20$ & $0 / 4$ & $(0)$ \\
$\geqslant 30$ & $77 / 187$ & $(41)$ & $<30$ & $2 / 41$ & $(5)$ \\
$\geqslant 40$ & $57 / 114$ & $(50)$ & $<40$ & $22 / 114$ & $(19)$ \\
$\geqslant 50$ & $23 / 30$ & $(77)$ & $<50$ & $56 / 198$ & $(28)$ \\
$\geqslant 60$ & $4 / 4$ & $(100)$ & $<60$ & $75 / 224$ & $(33)$ \\
\hline
\end{tabular}

risk categories, based on established criteria, ${ }^{9}$ with the highest risk associated with having visited the Indian subcontinent), number of siblings, number of children, and respondent's children having attended a crèche. Respondents were asked if they had ever received hepatitis A vaccine.

Respondents were asked to provide $5 \mathrm{ml}$ of blood and a saliva sample, which was obtained with a specially designed swab. When there was consent and no contraindication, each participant then received a single dose of hepatitis A vaccine (Havrix SmithKline Beecham, Monodose, 1440 ELISA units). Serum and saliva samples were refrigerated, before transportation to the Virus Reference Division, at the Central Public Health Laboratory, Colindale, within 48 hours. Serum was tested for IgG anti-HAV with an antibody capture radioimmunoassay (GACRIA), and was confirmed with a total antibody competitive radioimmunoassay (COMPRIA). ${ }^{10}$ Saliva samples were tested by GACRIA alone. Single and multivariable analyses were performed with GLIM statistical software. ${ }^{11}$ Employees' company occupational health records were reviewed for cases of viral hepatitis.

\section{Results}

Completed questionnaires were obtained for 157 of the 185 high risk employees (85\%), and for 84 of the 123 employees (68\%) with no known occupational risk, a $78 \%$ response rate. Twenty two ( $7 \%$ ) employees refused to participate and no contact could be made with a further $45(15 \%)$. Employees working at clean water sites, with no known occupational exposure to raw sewage, represented $50 \%$ of refusals and $62 \%$ of those who were uncontactable. The mean age of participants was 39 years, of refusals 42 years, and of those uncontactable 44 years. Saliva was obtained from all 241 respondents and serum samples from 210; the other 31 refused to provide blood. Where serum samples were not obtained, the respondent's hepatitis A immune status was defined by saliva anti-HAV results. Three cases with ambiguous test results and a further 10 cases who reported a previous hepatitis A vaccination were excluded from further analysis.

Overall, $79(35 \%)$ of the remaining 228 respondents were anti-HAV positive, including $22(19 \%)$ of those under 40 years and 57 $(50 \%)$ of those $\geqslant 40$ (table 1 ). Anti-HAV was independently associated with the subject reporting occupational exposure to raw sewage most of the time (odds ratio 3.73, 95\% CI 1.48 to 9.37). Other independently significant predictors of infection were: older age, having visited India, having $\geqslant 5$ siblings, and having $\geqslant 1$ children (table 2). Associations significant in single, but not in multivariable analyses, included: total duration in employment related to sewage; most of such employment spent working in sewers; having been splashed by raw sewage $\geqslant 20$ times; birth outside of the United Kingdom; education not having obtained an ordinary or higher vocational training certificate (roughly equivalent to not having completed high school); and having a child who attended a crèche. There was no significant association with ethnicity or with contact with treated sewage.

Respondents initially judged by line managers to be in high risk jobs were not significantly more likely to be anti-HAV positive: $46 \%$ (18/ $39)$ of sewerage workers, $40 \%$ (21/52) of flushers and fitters, $29 \%(16 / 56)$ of electricians and supervisors, compared with $30 \%(24 / 81)$ of clean water manual employees. Company records showed no cases of viral hepatitis among the study respondents or among sewerage workers in the five years before the study. Excluding the vaccinated cases, the saliva GACRIA was $98.6 \%$ sensitive $(95 \%$ CI $92.3 \%$ to $100 \%$ ) and $100 \%$ specific (95\% CI $97.2 \%$ to $100 \%)$ compared with results on the matched serum specimens.

\section{Discussion}

This study shows a significantly increased risk of hepatitis A infection, independent of known risk factors, in workers who reported often being occupationally exposed to raw sewage. By contrast, there was no association with exposure to treated sewage. The significant association of infection with other known risk factors suggests

Table 2 Potential risk factors with which anti-HAV status was independently significantly associated (best fit logistic regression model)

\begin{tabular}{|c|c|c|c|c|c|c|}
\hline \multirow[b]{2}{*}{ Factor } & \multirow[b]{2}{*}{ Units } & \multicolumn{2}{|c|}{ Anti-HAV positive } & \multirow[b]{2}{*}{ Odds ratio } & \multirow[b]{2}{*}{ (95\% CIs) } & \multirow[b]{2}{*}{$p$ Value } \\
\hline & & Yes & No & & & \\
\hline \multirow[t]{2}{*}{ Travelled to India } & No & 73 & 148 & 1.0 & & \\
\hline & Yes & 6 & 1 & 12.2 & $(1.4 \text { to } 563)^{\star}$ & $0.008^{\star}$ \\
\hline \multirow[t]{2}{*}{ Brothers or sisters } & $0-4$ & 51 & 140 & 1.00 & & \\
\hline & $\geqslant 5$ & 28 & 9 & 8.87 & (3.43 to 22.9 ) & $<0.0001$ \\
\hline \multirow[t]{3}{*}{ Exposure to raw sewage } & None of the time & 22 & 57 & 1.00 & & \\
\hline & Some of the time & 27 & 72 & 1.14 & (0.50 to 2.59$)$ & \\
\hline & Most of the time & 30 & 20 & 3.73 & (1.48 to 9.37$)$ & 0.0079 \\
\hline Aget & 10 -year increments & & & 3.05 & (1.93 to 4.82$)$ & $<0.0001$ \\
\hline \multirow{2}{*}{ Children } & None & 11 & 59 & 1.00 & & \\
\hline & Some & 68 & 90 & 2.70 & (1.10 to 6.64$)$ & 0.024 \\
\hline
\end{tabular}

$\star$ Exact limits and $\mathrm{p}$ value from Fisher's exact test. 
that the results of the study are valid. The lack of association with duration of occupational exposure, in the multivariate analysis, can be accounted for by its close correlation with respondents' age. Unlike previous studies, ours attempted to relate infection to actual indicators of occupational exposure. In the absence of any obvious objective marker a subjective measure was used. The outcome suggests that employees in water and sewerage companies can identify when they have been at occupational risk of infection. However, the study does not provide insight into the possible contribution to HAV infection of workers' failing to follow prescribed protective work practices.

The non-response rate of $22 \%$ (67 employees) was mainly due to failure to make contact with employees who were working on other shifts or on leave, rather than to refusals to participate. A pragmatic decision was made not to return to worksites which had been visited often over a period of months, in the hope of recruiting the remaining few eligible employees. Greater effort was made to recruit eligible employees who were known to have been at possible occupational risk of HAV infection, of whom only $6 \%$ refused. The good response rate, supported by the similar age of respondents and non-respondents, suggests little nonresponse bias. Cases of clinical HAV infection among employees are unlikely to have been missed because it is the duty of managers and safety advisers to report all cases of jaundice to the company's occupational health medical adviser. All absences from work are also coded by cause on the company's payroll system, which flags any notifiable cases which are then reported to the medical adviser. Water and sewerage company practice is for sewage and sewerage workers to wear protective overalls, gauntlets, hair nets, and hard hats when engaging in potentially hazardous work. They receive regular education which includes injunctions not to smoke or eat in hazardous situations. Specific questions on adherence with best practice were not included in the questionnaire as we considered that respondents would give biased responses when interviewed by company staff. Hepatitis A vaccination status was determined by respondents' histories, without accessing general practitioner (GP) records. This could have resulted in underestimates. However, hepatitis A vaccine was relatively new and we judged that the practical difficulties involved outweighed the benefits of this approach.

It is incumbent on employers to conduct risk assessments of hazards arising from work. ${ }^{12}$ With the increased demand for multiskilled and multipurpose workers in water and sewerage companies, employees are increasingly moving in and out of high risk jobs. This may explain why current job categories did not reliably reflect previous exposures in those judged to have been at risk of occupational exposure to sewage. Employees who were assessed as likely to often have occupational contact with raw sewage should therefore have their immunity to HAV ensured before starting such work. Frequent contact is currently interpreted by Thames Water Utilities as at least weekly con- tact. It has been difficult to measure risk precisely because of daily variations in job responsibilities and more precise measurements would be useful. Vaccination policy options for those employees who are likely to engage in high risk work include: testing all such employees and recalling anti-HAV negative workers for vaccination (one visit for all selected employees and a further two visits for vaccination); simultaneously testing and vaccinating all, with a follow up visit for the second dose of vaccine for susceptible workers; or vaccinating all such employees without initial testing (two visits for all). In view of the low anti-HAV prevalence in younger employees, hepatitis A vaccination without previous testing may be most cost effective, but measurement of immune status may be indicated in older employees.

If a prevaccination anti-HAV testing policy is adopted, the $100 \%$ specificity of the salivary GACRIA, when compared with serum testing, means that the saliva test would be suitable for employees who are reluctant to provide a serum sample (as was the case in this study), in that those in need of vaccination are unlikely to be erroneously considered HAV immune and denied vaccine. A small proportion of those who are naturally immune to HAV (probably $<1$ in 50 ) would be offered HAV vaccine unnecessarily because of a false negative GACRIA. We suggest that a hepatitis A vaccination policy includes a cost effectiveness analysis. This should take into account the economic costs of anti-HAV testing and vaccinations, the opportunity costs for health and safety staff and employees, and the age dependent likelihood of natural immunity to HAV infection. The results of the study have been disseminated to other major water utility companies through the Water Industry Occupational Health Advisers Group.

This study was commissioned and funded by Thames Water. We aknowledge the assistance of Gail James (Thames Water), and from the Public Health Laboratory Service Jane Saunders for data and sample collection, Bina Patel for laboratory support, and Mary Ramsay for advice in the design of the questionnaire.

1 Koff RS. Clinical manifestations and diagnosis of hepatitis A virus infection. Vaccine 1992:10(suppl 1):S15-17.

2 Salisbury DM, Begg NT, eds. Immunisation against infectious disease. London: Department of Health, HMSO, 1996.

3 Heng BH, Goh KT, Doraisingham S, et al. Prevalence of hepatitis A virus infection among sewage workers in Singapore. Epidemiol Infect 1994;113:121-8.

4 Skinhoj P, Blain Hollinger F, Hovind-Hougen $\mathrm{K}$, et al. Infectious liver diseases in three groups of Copenhagen workers: correlation of hepatitis A infection to sewage exposure. Arch Environ Health 1981;36:139-43.

5 Poole CJM, Shakespeare AT. Should sewage workers and carers for people with learning disabilities be vaccinated for
cole carers for people with learning disabilities be vaccinated for hepatitis A? BMf 1993;306:1102.

6 Schlosser O, Rodot-Thoraval F. Exposion professionelle aux eau usees et risque d'hepatite virale A. Arch Mal Prof 1995; 56:23-7.

7 Hepatitis A vaccine. Communicable Disease Report CDR Wkly Anonymous. 1992;2:1

8 Control of Substances Hazardous to Health, Regulations 1994, Approved Codes of Practice, 2nd ed. 1997. ISBN 071761308 9.

9 Behrens RH, Collins M, Botto B, et al. Risk for British travellers of acquiring hepatitis A. BMF 1995;311:193.

10 Parry JV, Perry KR, Mortimer PP. Sensitive assays for viral antibodies in saliva: an alternative to tests on serum. Lancet 1987; ii: $72-5$.

11 Francis B, Green M, Payne C, eds. The GLIM system release 4 manual. Oxford: Oxford University Press, 1993.

12 Management of Health and Safety at Work Regulations 1992. ACOP ISBN 0118863304. 